\title{
Correction: Constructing collective identities and solidarity in premiers' early speeches on COVID-19: a global perspective
}

Martina Berrocal (D), Michael Kranert (1), Paola Attolino, Júlio Antonio Bonatti Santos, Sara Garcia Santamaria, Nancy Henaku, Aimée Danielle Lezou Koffi, Camilla Marziani@D, Viktorija Mažeikienè, Dasniel Olivera Pérez, Kumaran Rajandran \& Aleksandra Salamurović

Correction to: Humanities and Social Sciences Communications https://doi.org/10.1057/s41599-021-00805-x, published online 27 May 2021.

The affiliation of one of the authors was wrongly stated as:

Kumaran Rajandran, School of Humanities, Universiti Sains, Sains, Malaysia

This has now been corrected to:

Kumaran Rajandran, School of Humanities, Universiti Sains Malaysia, George Town, Malaysia

This has been corrected in all versions of the paper.

Published online: 24 June 2021

(i) Open Access This article is licensed under a Creative Commons Attribution 4.0 International License, which permits use, sharing, adaptation, distribution and reproduction in any medium or format, as long as you give appropriate credit to the original author(s) and the source, provide a link to the Creative Commons license,

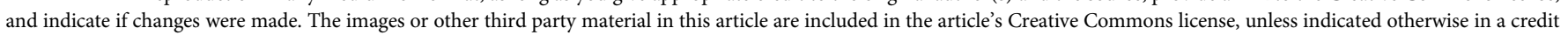

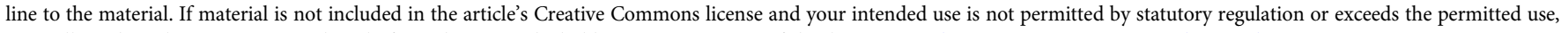
you will need to obtain permission directly from the copyright holder. To view a copy of this license, visit http://creativecommons.org/licenses/by/4.0/.

(C) The Author(s) 2021 